application forms: The Training Administrator, The Tavistock Clinic, 120 Belsize Lane, London NW3 5BA.

An Advanced Cognitive Therapy Course will be held at the Department of Psychiatry, Edinburgh University from 24-28 June 1991. Fees: $£ 300$ (non residential). Further information: Dr Chris Freeman, Royal Edinburgh Hospital, Morningside Terrace, Edinburgh EH1 5HF.

The Second Congress on Mental Health and Deafness will be held in Namur, Belgium, from 9-11 May 1991. Further information: Secretariat of the Second Congress on Mental Health and Deafness, La Bastide, Avenue Vauban, 8, B-5000 Namur, Belgium (telephone 32812252 55; fax 328123 1445).

A conference entitled Women Doctors and Their Careers will take place on 29 April 1991 in the Clarendon Wing of the General Infirmary, Leeds. Fee: $£ 45$. Further information: Julia Dunning, Health Visitor, PO Box 12, Whitley, Goole, North Humberside DN14 0JT (telephone 0977 662560).
A study day for psychiatrists entitled Current Issues in Transracial Adoption, organised by NETCAP (North East Thames Child and Adolescent Psychiatrists) will be held on 12 June 1991 at the Robin Brook Centre, St Bartholomew's Hospital, West Smithfield, London EC1. Further information: Dr Guinevere Tufnell, Child \& Family consultation Centre, Shernhall Street, London E17 (telephone 081509 0424).

The Society for Existential Analysis will be holding Forums on 3 May 1991-Death, Dying and Being (With) and on 7 June 1991-The Philosophical Issues of Post-Traumatic Stress Syndrome. Further information: The Secretary, Society for Existential Analysis, School of Psychotherapy \& Counselling, Regent's College, Inner Circle, Regent's Park, London NW1 4NS (telephone 0716026154 ).

A two-day workshop entitled Supporting SelfAdvocacy: The Advisors' Role will be held on 23 and 24 May 1991 at the King's Fund Centre, London. Closing date for applications: 19 April 1991. Further information: Andrea Whittaker or Melanie Kornitzer, King's Fund Centre, 126 Albert Street, London NW1 7NF (telephone 0712676111 ).

Contributions for this section should be submitted two months in advance of publication.

\title{
Back to the future
}

\section{Basic sciences}

But if that Variety of Symptoms, that often affects the Body, under those Disorders, arise from a wrong Turn of the Fancy. I hope these Gentleman will be so candid as to inform us, from whence that wrong Turn of the Fancy it self arises, that is supposed to give Being to all those Symptoms: For I deny, that the Thoughts themselves can ever start from a regular Way of Thinking, without inferring, at the same Time, a change in the Motions of the Animal Fibres; whether the Object causing that irregular Turn of Thought, was primarily struck upon the Mind, and so acted upon the Mind, and so acted upon the Body, by first acting upon the Passions: or was first lodg'd in the Fibres, and, by affecting the material Organs, after that, disconcerted the Passions: and after them, the Mind: I say, which way soever the Shock was received, it's impossible that the mind can suffer, and the Body be unaffected at the same
Time, \& vice versa. For, we perceive, in those violent Passions or Transports of Anger, that are big enough to raise a temporary Madness, if, at the same Time, they do not disconcert the Animal Organs; upon the Abatement of these Motions, the Mind will naturally subside, settle and recover its former State of Tranquility again; which is far otherwise, when the Organs, that support the Passions, are affected, for then the Madness or Discomposure holds on, and the Patient often continues under its Influence whole Nights and Days without the least Intermission.

\section{Reference}

Robinson, N. (1729) A new system of the spleen, vapours, and hypochondriack melancholy: wherein all the decays of the nerves, and lownesses of the spirits, are mechanically accounted for. London: Butterworth.

Researched by Susan Floate, Librarian. 